\title{
8. klasse som kreative producenter af fremtidens velfærdsteknologi - konstruktionisme, problemløsning og dialog
}

\section{Jacob Nielsen}

Lektor

Embodied systems for Robotics and LearningMærsk Mc-Kinny Møller Instituttet, Syddansk Universitet.

\section{René Pedersen}

\section{Lærer}

Ejerslykkeskolen, Odense.

\section{Gunver Majgaard}

\section{Lektor}

Embodied systems for Robotics and Learning Mærsk Mc-Kinny Møller Instituttet, Syddansk Universitet.
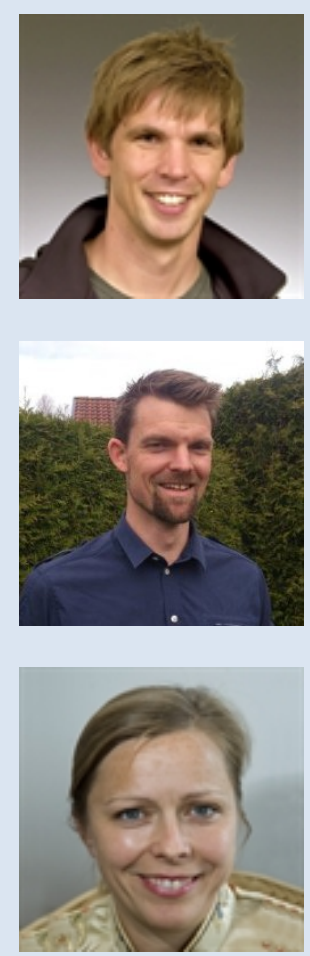


\section{Abstract}

Gennem denne praksisbaserede artikel viser vi et eksempel på, hvordan 8. klasses elever kan bygge og programmere interaktive robotartefakter med Arduino. Arduinoteknologien anvendes bl.a. i Makerspaces, hvor børn og unge udforsker det 21. århundredes teknologi, som forbinder den fysiske og virtuelle verden.

Undervisningen var to-delt og bestod af indledende opgaver efterfulgt at et friere og mere eksperimenterende projektforløb. Eleverne konstruerede i det friere forløb f.eks. et løbende vækkeur, hurtig-bold-måler, motionsmotivatoren og pulsindikator. Det faglige område kredsede om programmering, kredsløbsteknik, robotteknologi og teknisk engelsk.

Læringen foregik efter et konstruktionistisk tilsnit, med fokus på eksperimenter og problemløsning. Særligt fokus på dialog i forbindelse med problemløsning var omdrejningspunkt i læreprocessen, hvor systemet og dets delelementer blev udfoldet. Eksemplet viser en udfordrende og farbar vej for skoler som vil eksperimentere med robotteknologi og programmering.

\section{Engelsk abstract}

In this practice-based article, we present an example of how eighth grade students can build and program interactive robotic artifacts using Arduino. The Arduinotechnology is e.g. used in Maker Spaces, where students are exploring 21st century technologies that connect the physical and virtual world.

The training was two-fold: and consisted of specified introductory tasks followed by more experimental projects. Within the experimental projects, the students e.g. constructed a running alarm clock, ball-meter, exercise-motivator and a heart rate indicator. The subject areas touched upon were primarily programming, building circuits, robotics and technical English.

The didactical planning was inspired by constructionist learning philosophy, with a focus on experimentation and problem solving. Special focus on dialogue in problem solving was the focal point of the learning process. The example shows a challenging yet viable option for schools who want to experiment with robotics and programming.

\section{Indledning}

Denne praksisbaserede artikel omhandler, hvordan 8. klasses elever kan bygge og programmere interaktive robotartefakter med robotteknologiværktøjet Arduino. Arduino (2015) er en alsidig robotteknologisk platform, som kan anvendes i folkeskolen, ingeniørskolerne, på designuddannelserne og af hobbyfolk til at udvikle fysiske interaktive artefakter f.eks. hastighedsmålere, http://www.lom.dk 
intelligente tasker, intelligente skraldespande eller pulsmålere. Teknologien minder om LEGO Mindstorms, men er mere fleksibel og mere kompliceret, idet man kan kombinere teknologien med materialer fra formningslokalet. Arduino er desuden et af værktøjerne som anvendes i Makerspaces, hvor børn og unge udforsker det 21. århundredes teknologi, som forbinder den fysiske og virtuelle verden. Makerspaces er ofte udstyret med 3D-printere og robotteknologi. Intentionen i dette projekt er at udforske, eksperimentere, skabe og være kreativ, imens man samtidig udvikler en dybere forståelse for hverdagens og det 21. århundredes teknologi. Robotteknologi, wearables og programmering er ifølge NMC Technology Outlook begreber, som vil udfolde sig i de skandinaviske skoler de næste fire-fem år (Johnson et al, 2015).

Undervisningsformen var inspireret af tankerne fra Makerspaces og baseret på ideen om konstruktionistisk læring (Papert, 1993), som understøtter skabende og eksperimenterende læreprocesser. Eleverne skulle formulere koncepter ud fra problemstillinger inden for et velfærdsteknologisk domæne.

Undervisningen blev afviklet over fire uger, tre uger nogle få timer om ugen og den sidste uge på fuld tid. I første omgang gennemgik børnene allerede beskrevne eksperimenter (Fitzgerald \& Hiloh, 2012). På den måde kunne de lære teknologiens muligheder og begrænsninger at kende. Derefter formulerede de i mindre grupper ideer og koncepter til egne artefakter, som blev udviklet i den sidste uge. Undervejs lavede de små videoer af deres prototyper.

I forbindelse med anvendelse af ny teknologi i klasserummet er der mange faldgrupper, som man skal navigere rundt om. Der vil ofte være problemer med, at teknologien ikke gør, som man regner med. Eleverne kan måske miste interessen, hvis teknologien driller. Derudover skal der også være læringsmål som rækker ud over at lære teknologien at kende, ellers bliver det blot undervisning i en ny "gadget"(Majgaard, Hansen, Bertel, Pagh, 2014). Der kan forekomme kaos og forvirring i klassen, når man ændrer på undervisningsformen. Det kræver en særlig form for disciplin at arbejde problemorienteret konstruktionistisk med teknologi. Både lærer og elever skal kunne trives med en vis grad af kaos, som ofte følger af de lidt mere åbne eksperimenter.

Forløbet var en del af Dansk Naturvidenskabsfestival 2014. Projektet var et græsrodsprojekt i den forstand, at det var klassens fysik/kemi- og matematiklærer, som gik foran og ansøgte om midler til teknologi og lærebøger. Projektet blev gennemført sammen med to forskere fra Syddansk Universitet, som i forvejen havde erfaring med at anvende Arduinoteknologien til undervisning af ingeniørstuderende. Denne artikel er blevet til i samspil mellem underviser og forskere. 
I artiklen vil vi gerne gøre rede for vores erfaringer med anvendelse af Arduino i en konstruktionistisk sammenhæng. Konkret fors $\emptyset$ ger vi at besvare følgende spørgsmål:

Hvordan kan Arduino og konstruktionistisk læring berige undervisningen i 8. c? - herunder styrker og faldgrupper ved teknologi og et konstruktionistisk forløb.

For at besvare spørgsmålet, deltog vi aktivt som både tekniske vejledere og observatører i en stor del af forløbet. Slutpræsentationen af prototyper blev optaget på video. Elever og lærer besvarede spørgeskemaer.

Unders $\varnothing$ gelsesmetoden er inspireret af Design-based Research, som er en kvalitativ metode der egner sig til unders $\varnothing$ gelser af hvordan teknologi og undervisningsdesign kan underst $\varnothing$ tte læring i klasserummet (Akker et al., 2006; Majgaard, Misfeldt, \& Nielsen, 2011).

I det efterfølgende introduceres vores forståelse af konstruktionistisk læring som vores læringsteoretiske udgangspunkt. Derudover præsenteres teknologien og metoden.

Dernæst præsenteres illustrative eksempler fra undervisningen og en præsentation af underviserens og elevernes erfaringer fra forløbet med udgangspunkt i spørgeskemaerne. Endvidere diskuteres læringspotentialerne af anvendelse af Arduino ud fra følgende temaer: Affordance og konstruktionisme; Elever som kreative producenter i designforløb; Debugging og læring og Fysik/kemi - Elektronisk og digital styring. Til slut sammenfattes og konkluderes der.

\section{Baggrund: Konstruktionistisk læring og den teknologiske platform}

Projektet bygger på en konstruktionistisk tankegang (Papert, 1993; Resnick, 2008; Nielsen, 2014; Majgaard, 2014). Konstruktionisme er baseret på Paperts (1993) tanker om eksperimentel læring. Den lærende eksperimenterer sig frem til ny viden. Teknologien er en slags "object to think with", hvor den lærende sammensætter komponenter i en ny logisk orden. Systemet giver forskelligt feedback afhængigt af, hvordan det er sammensat. En diode lyser måske som $\emptyset$ nsket, hvis den vender rigtigt og det $\varnothing$ vrige kredsløb er forbundet korrekt. Den lærende problemløser som led i sin tilegnelse af ny viden. Den nye viden tilpasses eksisterende viden og nye kognitive stukturer dannes.

De lærende skal ifølge denne teori ikke indledningsvist have lange teoriske foredrag - i dette tilfælde om sensorer og programmering, med et efterfølgende mindre eksperiment, som så efterviser teorien. Ideen er at de lærende kun får den mest nødvendige information om teknologien - kun nok til lige at sætte dem i gang. Derudover informeres de om rammerne for forsøgene, hvor lang tid de har, hvor de skal arbejde sig hen og hvad formålet http://www.lom.dk 
er. Ideen er, at de lærende selv og med hinanden skal erfare sig frem til nye og dybere forståelser. En forståelse som er bundet til en konkret erfaring.

Formålet med Fysik/kemi i 8. klasse er bl.a. at bidrage til, at eleverne erkender, at naturvidenskab og teknologi er en del af vores kultur og verdensbillede (Fællesmål 2014 - Fysik/kemi - kap 1 § 15). Den konstruktionistiske undervisningsform kan forhåbentligt bidrage til at udvikle elevernes interesse og nysgerrighed for teknologi og give dem lyst til at lære mere. Derudover får eleverne konkrete erfaringer med udvikling af funktionelle prototyper.

Ulemper ved den konstruktionistiske undervisningsform kan være, at den lærende ikke altid får sat ord på det han lærte, og derfor kan have svært ved at gøre rede for sin nye viden. Det er derfor vigtigt, at der i forløbet tages $h \varnothing j d e$ for dette fx ved at evaluere, sætte fagtermer og begreber på de nye erfaringer. Herved kan erfaring forvandles til gangbar viden, som kan udveksles og formidles til andre. Der vil dog ifølge Schön (2001) altid være dele af en sådan erfaret og praksisnær viden som forbliver tavs, og kun vil kunne åbenbares og bringes $\mathrm{i}$ anvendelse i forbindelse med den lærendes praktiske arbejde med teknologien. Ligeledes bliver læringen gennem den konstruktionistiske form ofte være individualiseret, fordi den lærende kun kommer i kontakt med de læringsområder, som han/hun beskæftiger sig med under f.eks. et projekt. Derfor er det væsentligt at man i forløbet også sørger for at dele sine erfaringer på tværs efterfølgende for at opnå en mere fælles forståelse og platform at bygge videre på.

\section{Den teknologiske platform Arduino.}

De indledende forberedelser inkluderede valg af platform til at arbejde med teknologi på prototypeniveau. Til dette faldt valget på Arduino, da det er en vidt udbredt, supporteret og eksempelrig open-source platform med en stor og gavmildt delende brugerskare, så man via et væld af forums, blogs og webshops kan finde eksempler på både opbygning af elektroniske kredsløb og kode, der passer til. Det, at platformen er open source gør også, at der er mange firmaer, der udvikler delkomponenter og udvidelser til platformen, og dermed bliver det muligt at lave prototyper, der kan det samme som de avancerede teknologiske produkter vi bruger i vores hverdag.

Vores valg faldt på Arduino Starter Kit'et (http://arduino.cc/en/Main/ArduinoStarterKit). Begrundelsen bag dette er, at dette kit inkluderer en rigtig god og eksempelrig bog (Fitzgerald \& Hiloh, 2012) med opskrifter, der starter fra simple rene elektriske kredsløb man opbygger for at få en basal kredsløbsforståelse. Derefter går man videre til at forbinde de elektroniske komponenter med Arduino-board'ets mikrocontroller og skriver de første simple programmer, der langsomt fører én ind i, hvad det vil sige at programmere. 


\section{Metode - projektets forløb opdelt i indledende opgaver og projektfaserne}

Projektet, Fremtidens Velfærdsteknologi, blev udført som et samarbejde mellem Ejerslykkeskolen og Mærsk Mc-Kinney Møller Instituttet (MMMI), Syddansk Universitet. Ideen til projektet udsprang af et tidligere samarbejde mellem ovennævnte parter om robotteknologi i folkeskolen og trækker tråde fra projektet ISI2015 (Sølberg, 2015; Binau \& Mortensen, 2015), hvis formål bl.a. var at udvikle metoder for innovativ undervisning i naturfagene.

Projektet blev til som en del af Naturvidenskabsfestivalen 2014, og finansiering på i alt 15.000,00 DKR til materialer kom i stand via Nordea-fondens naturvidenskabelige festivalspulje.

Projektet involverede en 8. klasse med 21 elever på Ejerslykkeskolen over en periode på i alt fire uger i efteråret 2014.

Nedenstående figur 1 skitserer forløbet og timeforbruget under projektet, og dette uddybes yderligere nedenstående.

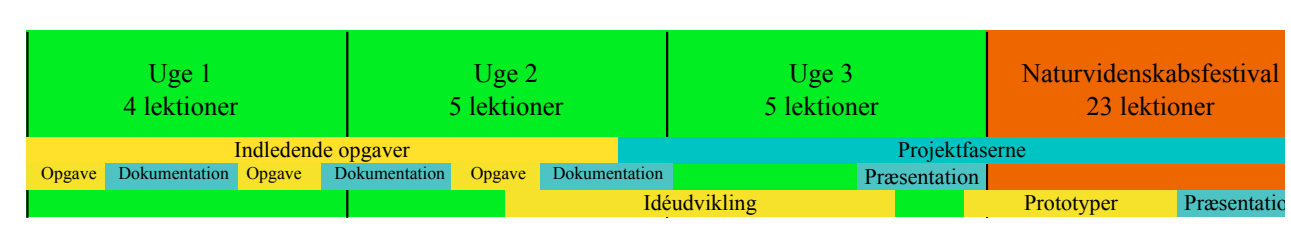

Figur 1. Skitsering af forløbet af projektet "Fremtidens Velfærdsteknolgi" over en fire ugers periode med de to overordnede inddelinger, Indledende opgaver og Projektfaserne

\section{Indledende opgaver (De deduktive aktiviteter)}

Denne del af projektforløbet omhandlede introduktion til teknologien; hvad er Arduino, hvad kan man med det, og hvordan opbygger man kredsløb, programmerer, tester og fejlsøger dem. De indledende opgaver kan sammenlignes med Darsøs begreb "prejekt", som betegner "en målsøgende proces, der foretages af et team, som forsøger at afdække et område ved at generere spørgsmål og viden og ved at holde beslutningsrummet åbent, indtil der er hentet passende information" (Darsø 2012 p.67)

Vi valgte som nævnt at benytte Arduino Starter Kit. Dette sæt inkluderer den engelsksprogede projektbog, The Arduino Projects Book (Fitzgerald \& Hiloh, 2012), et Arduino UNO mikrokontroller-board, et såkaldt breadboard til at opbygge elektroniske kredsløb på samt ledninger og komponenter til at bygge de projekter bogen beskriver.

I arbejdet med opgaverne blev klassen inddelt i ni grupper med to-tre elever. 
Den første opgave eleverne i 8.c blev udsat for introducerer Arduino, beskriver og illustrerer de forskellige komponenter og instruerer i hvordan man samler kit'et og installerer den nødvendige software på PC (Fitzgerald \& Hiloh, 2012, s.4-19). Eleverne blev fra undervisernes side opfordret til, at læse alt materialet og følge instruktionerne nøje for alle opgaverne.

Dernæst arbejdede eleverne med opgaverne: (1) "Get To Know Your Tools" som omhandler opbygning af simpelt elektronisk kredsløb med kontakter, lysdiode og en modstand. Der er i denne opgave ingen programmering; (2) "Spaceship Interface" som omhandler opbygning af et kredsløb med 3 lysdioder med formodstande og forbindelse til Arduino mikrokontrollerens digitale porte samt en kontakt, der ligeledes forbindes til en digital port. Dette projekt involverer programmering af mikrokontrolleren og dermed brug af PC og Arduino-softwaren; (3) "Love-o-meter" der omhandler opbygning og programmering af et kredsl $\emptyset \mathrm{b}$ til at måle temperatur. Til denne opgave benyttes også 3 lysdioder med formodstande forbundet til Arduino'ens digitale porte samt en temperatursensor, der forbindes til en analog indgang på arduino'en (Fitzgerald \& Hiloh, 2012, s. 20-51).

Eleverne blev ved hver færdiggørelse af en opgave bedt om at videodokumentere deres løsning, og herunder også give en forklaring på deres opbygning, hvilke komponenter den inkluderede og hvordan det samlede system fungerede.

Derudover opsamlede vi også data på dette forløb i form at undervisernes observationer undervejs. Hvilke spørgsmål blev stillet? Hvilke typer fejlfinding blev der bedt om hjælp til?

\section{Projektfaserne (De induktive aktiviteter)}

Den sidste del af projektet har vi valgt at kalde projektfaserne, da det er denne del, hvor eleverne arbejder projektorienteret inden for domænet velfærdsteknologi. Som basis for projektfaserne blev nedenstående læringsmål opstillet og præsenteret for eleverne:

Læringsmål - Efter projektet forventes det at eleverne:

- har fået et indblik i teknologien bag hverdagens teknologi: Hvordan opbygges hardware og software?

- kender alle elementer af en innovativ proces fra ide over faglig fordybelse til fremstilling og præsentation af en prototype.

- har fået udviklet jeres kompetencer i samarbejde, faglig fordybelse, kritisk tænkning samt formidling.

- kender til grundprincipperne ved kodning. Hvordan opbygges et program?

- kender forskellige kommandoer og funktioner til programmering.

- kan bygge og identificere forskellige elektriske kredsløb, herunder serieog parallelforbindelser. 
- kan læse og tegne enkle elektriske diagrammer.

- kender Ohms lov.

- kan fremstille en arbejdstegning med angivelse af mål og med det rette målestoksforhold.

- ved hvad det vil sige at pitche en idé.

Idéudvikling. I denne første fase udviklede eleverne idéer ift. til det overordnede problemområde, velfærdsteknologi i grupper af fire elever. Den første del af ideudviklingsfasen blev afviklet som en brainstormfase, hvor hver gruppe producerede en mængde papirlapper med associationer til begrebet velfærdsteknologi. Disse ideer blev udsat for en let kategorisering, med intuitive argumenter som "de minder om hinanden". Hensigten var at få et overblik over udbyttet af brainstormens samlede idekatalog og finde de felter hvor ideerne kunne kombineres og komplementere hinanden. De foreløbigt bedste koncepter blev udviklet via cirkelskrivning mellem gruppernes medlemmer. Ved cirkelskrivning forstås en proces, hvor eleverne i grupper svarer på en problemstilling, der kræver ideudvikling. Hver elev i en gruppe skriver en mulig løsning på opgaven og alle sender efter en fastsat tid papiret videre til den næste, der udvikler videre på ideen osv. indtil det enkelte papir er nået bordet rundt. Til sidst har gruppen udviklet et antal løsninger på en problemstilling svarende til antallet af personerne i gruppen. Denne metode er en variation over "6-3-5" (Rohrbach,1969). De resulterende overordnede konceptuelle modeller blev alle omsat til et mindmap vha. MindMeister (http://www.mindmeister.com), der afspejlede deres teknologiske grundlag og gav et overblik over hvilke sensorer og aktuatorer der tænktes anvendt.

Præsentation af Idéer. Grupperne forberedte præsentation af deres ideer udviklet på baggrund af deres mindmaps. Præsentationerne gav mulighed for både feedback fra undervisere og de andre grupper og blev dermed udgangspunkt for den efterfølgende udvikling af prototyper.

Prototypeudvikling. Udviklingen af prototyper forløb som en iterativ, inkrementel proces. Det at processen er iterativ betyder, at man gentagne gange hhv. designer, bygger/ændrer prototyper, og evaluerer i løbet af udviklingsprocessen. se f.eks. (Rogers et al., 2011, s. 331-332). Man taler også om at udviklingsprocessen er inkrementel, når man netop gennem iterationerne kommer tættere og tættere på målet for det man udvikler. Dette er en fagterm der benyttes meget under især softwareudvikling - se f.eks. (Larman \& Basili, 2003). Under processen udviklede og testede eleverne delelementer af deres idé, dels som konceptuelle designs til at starte med og efterfølgende som prototyper realiseret via Arduino elementer og papir, pap og andre traditionelle formningsmaterialer, f.eks. farver, lim, piberensere, træ m.m. I denne proces byggede, ændrede og forfinede de således I $\emptyset$ bende deres prototyper indtil de var klar til at blive præsenteret. De fik i denne fase 
mulighed for at arbejde med andre typer sensorer og aktuatorer end dem, der er en del af Arduino Starter Kit'et.

Præsentation af Prototyper. Som den sidste fase af projektet i festivalugen skulle eleverne præsentere deres færdige projekter for andre elever på skolen samt deres forældre. Præsentationerne blev arrangeret som stande, hvor man som besøgende kunne komme forbi og få en forklaring og demonstration af de enkelte projekter. Til præsentationen af hvert projekt skulle projektgrupperne forberede en poster, der beskrev de væsentligste elementer af deres produkt med fokus på synlighed og blikfang. Derudover skulle de øve sig på at pitche deres idé i forbindelse med demonstrationen af prototypen.

Derudover blev der også udleveret et spørgeskema (Google forms), der skulle besvares. Spørgsmålene her omhandlede projektet, oplevelsen af projektarbejdet, hvad der havde været let/svært, hvad man havde lært, og ens mening om det man havde fået lavet.

\section{Resultater}

\section{De indledende opgaver}

Vores data her er baseret på observationer af klassen og elevernes videooptagelser af Iøsninger med tilhørende forklaringer. De observationer vi gjorde under forløbet med de indledende opgaver fra Fitzgerald \& Hiloh (2012) er beskrevet herunder:

I forbindelse med introduktionsopgaven får langt de fleste grupper hurtigt samlet de træ-dele, der fungerer som platform for Arduino-boardet og breadboardet: Nogle får vendt delene forkert og må skille ad igen. Nogle få skal hjælpes med at tyde tegninger. Installationen af Arduino-softwaren på elevernes og skolens PC'ere forløber ikke let i alle tilfælde. Skolens PC'ere skal have ændret rettigheder for at kunne installere usb-driveren til arduinoboardet. De fleste grupper skal have hjælp til installationen. Der er en del læsestof i dette projekt, og der er stor forskel på, hvor meget der bliver læst. Nogle grupper deler det op, således at én bliver ansvarlig for at samle, mens en anden installerer. De første sider, der beskriver delene i kit'et bliver i de fleste tilfælde blot skimmet.

Opgaven "Get to Know Your Tools" tager ifølge bogen 30 minutter at gennemføre. Langt de fleste grupper springer direkte til instruktionerne i at opbygge kredsløbet, og får dermed ikke læst teorien om transducere, sensorer, aktuatorer, spænding, strøm og modstand m.m. til at starte med. De får i mange tilfælde heller ikke læst, om breadboardet og hvordan forbindelserne er inde i det. Der er i opgavebeskrivelsen fire illustrationer af kredsløb. Det første er ét, hvor man blot sætter spænding på et kredsløb med en lysdiode (LED) og en modstand, for at få LED'en til at lyse. Dette kredsløb, er 
ikke det, der er omdrejningspunktet i dette projekt, men mange af grupperne bygger det alligevel, fordi det ikke er gået op for dem, at det først er de næste kredsløb de skal bygge. Det næste kredsløb indeholder udover lysdiode og modstand også en kontakt, således at man kan tænde og slukke for lysdioden med kontakten. De næste to kredsløb gør brug af to kontakter til at illustrere hhv. seriel og parallelforbindelser. Under opbygningen af disse kredsløb er der en del grupper, hvor man er meget omhyggelig med at sætte komponenter $\mathrm{i}$ de terminaler, der har det eksakt samme nummer som i bogens illustrationer. De fejl som opstår under opbygningen af dette projekt er typisk at man får vendt lysdioden forkert, eller ikke får lavet en korrekt elektrisk forbindelse mellem to komponenter i breadboardet. Der er også enkelte grupper, hvor der vælges en forkert modstandsstørrelse. Når der spørges om hjælp, er det ofte fordi man har prøvet at opbygge kredsløbet, men ikke kan se at det virker som bekrevet i bogen. Nogle spørger ind til bestemte passager i bogen, som de ikke forstår. Det er f.eks. fagtermer, der er svære at forstå, eller som de ikke har kunnet finde forklaringen på - eller simpelthen at deres engelske ordforråd ikke slår til ift. at forstå, hvad de skal gøre. Enkelte er i stand til at løse deres fejl selv ved at følge opskriften igen. Videodokumentationen til opgaven viser $\mathrm{i}$ alle tilfælde, at eleverne har fået eksemplerne til at virke. Deres beskrivelser viser en god eller delvis forståelse af, hvad det er de har bygget. Der er enkelte misforståelser ift. komponenters roller og navne i kredsløbene. Bl.a. kaldes Arduino-boardet for "strømforsyningen", og modstandene kaldes for "ohm'ene". De fleste grupper er klar til at gå videre til næste opgave efter 45 60 minutter.

Opgaverne "Spaceship Interface" og "Love-o-Meter. I disse opgaver skal der både opbygges et kredsløb og laves et program. Eleverne er allerede her mere selvstændige i deres opbygning af kredsløbene, og får oftest valgt de rette modstandsværdier og vendt lysdioderne korrekt. Flere har problemer med at få programmerne til at virke. Der er flere grupper, der har indtastet linjenumrene fra bogen også, hvilket giver fejl, når de forsøger at køre programmet. En del får også fejl på tastefejl, hvor en variabel f.eks. ikke staves på helt samme måde forskellige steder i programmet, eller hvor man ikke får taget højde for brugen af store og små bogstaver $\mathrm{i}$ indtastningen af kommandoer. Mange af de spørgsmål, der kommer fra eleverne i disse projekter omhandler usikkerheden på, om det er hardwaren eller softwaren, der er skyld i, at ens projekt ikke virker. Løsningen kommer i mange tilfælde ved at gå instruktionerne igennem minutiøst, først for den skrevne kode, og derefter hardwaren. Vi oplever for disse opgaver en overvægt af fejl $i$ softwaren.

\section{Projektfaserne}

Resultaterne af projektfaserne er primært baseret på elevernes præsentationer af ideer og projekt, og de observationer der er gjort undervejs. 
Idéudvikling og præsentation af idéer. Ideudviklingen resulterede i følgende syv ideer:

- Det løbende vækkeur, der flygter når det ringer for at tvinge folk ud af sengen

- Hurtig-bold-måleren, der kan bestemme hastigheden af en boldt der bliver sparket til.

- Motions-motivatoren, der giver mad, bl.a. popcorn som belønning for fysisk aktivitet

- Pulsindikatoren, der viser hvor aktiv man er via en pulssensor.

- Vippemusen, hvor man skal vippe en genstand for at svare på et givent spørgsmål i en quiz. Når man vipper til højre svarer man ja, og venstre, nej.

- Den glade skraldespand, der siger tak og giver point, når man smider skraldet i skraldespanden og buh'er, når man rammer ved siden af.

- Indeklimasystemet, der hele tiden gør opmærksom på temperaturen i lokalet.

De endelige prototyper. På den sidste dag i naturvidenskabsfestivalsugen blev følgende projekter præsenteret:

- Det løbende vækkeur, der var blevet ændret fra at være løbende til kørende, og benyttede en til formålet indkøbt robotplatform (se figuren herunder ). Robotten fungerer således: Man sætter den på gulvet og tænder den. Efter den fastsatte tid er gået begynder den at bippe og køre. Kørslen er en kombination af tilfældige retninger og strækninger med fast hastighed. For at slukke vækkeuret skal man nå at trykke på en knap på toppen af robotten.
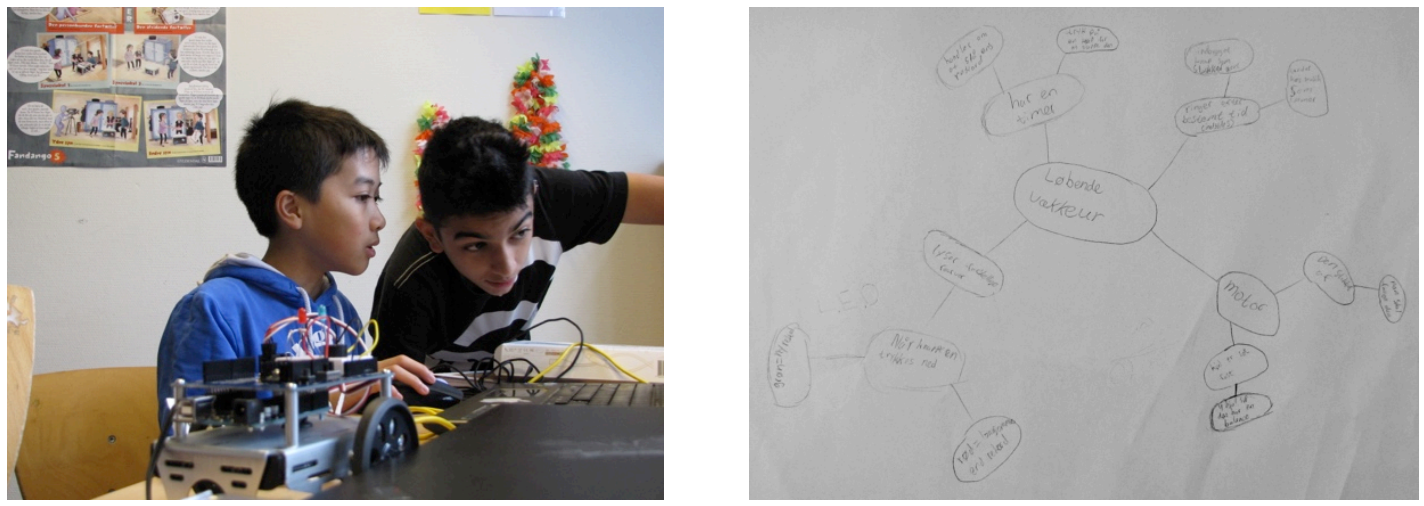

Figur 2. Det løbende vækkeur 
- Hastighedsmåleren blev udviklet til at estimere hastigheden af en sparket bold ved hjælp af en ultralydssensor. Der blev bygget en afskærmning for at undgå at sensoren blev ødelagt af bolden. Bolden skal sparkes mod ultralydssensoren indenfor en afgrænset bane, og efterfølgende beregnes hastigheden og vises på displayet. Hastigheden bliver beregnet ved løbende at måle på ændringer i afstand over tid fra bolden registreres til den når helt hen til sensoren. Det er hele tiden den højst beregnede hastighed, der vises på displayet. En af konklusionerne på forløbet blev, at der ofte er fejlmålinger, der resulterer i for $h \varnothing j t$ beregnede hastigheder.

- Til Motions-motivatoren blev der bygget et kredsløb, der kunne registrere fysisk aktivitet via et accelerometer. Accelerometeret registrerer ændringer $i$ acceleration i tre dimensioner, og kan dermed bruges til at give et fornuftigt estimat af, hvor meget man bevæger sig. Arduino opstillingen, der blev bygget omfatter således accelerometer og også en servomotor, der skal bruges til at tænde for en popcornmaskine. Programmet fungerer således at når der er registreret fysisk aktivitet med en vis intensitet over et bestemt stykke tid, så bevæger servomotoren sig til "tændt" positionen, hvilket svarer til at der tændes for popcornmaskinen - eller at der doseres en bestemt mængde popcorn.
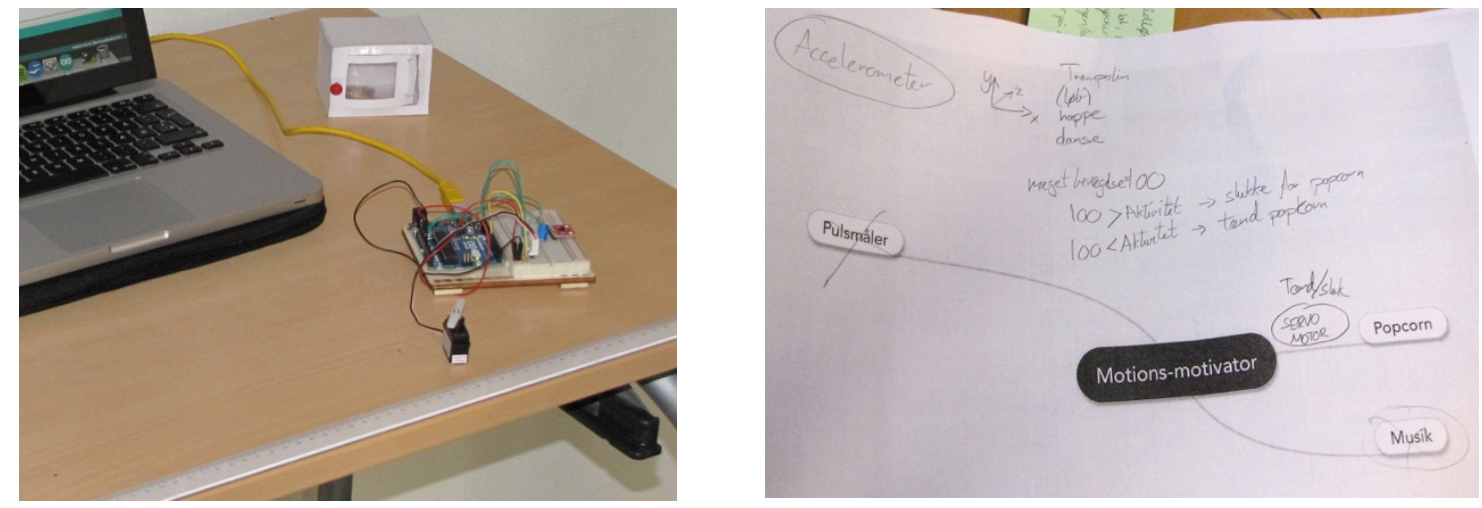

Figur 3. Motions-motivatoren

- Pulsindikatoren blev indkøbt fra http://pulsesensor.com efter at have unders $\varnothing$ gt muligheden for en byg-selv løsning. Pulssensoren blev forbundet til Arduino-boardet, og den medfølgende Arduino og PC software blev installeret. Pulssensoren viser dels pulsen via den lysdiode, der sidder på selve sensordelen og via 2 lysdioder i breadboardet, men sender også signalet videre via Arduino til PC'en, således at man kan følge brugerens puls grafisk på skærmen. Pulssensoren blev mest brugt som en demonstrator af muligheden for at måle folks puls før og efter fysisk aktivitet. 
Konkurrenceelementer blev dog udforsket, f.eks. hvem kan opnå den højeste puls på en fastsat tid.

- Vippe-musen beskrevet i ovenstående afsnit blev omdøbt til A/T Quizzen, og konceptet blev ændret til at man som aktiv deltager i quizzen skal bevæge sig på tværs af klasselokalet for at svare hhv. ja eller nej på et givent spørgsmål. Der blev bygget en model-prototype af et klasseværelse, hvor man så som deltager skal bevæge en piberenser quizfigur fra den ene side af papkasseklassen til den anden side, for at aktivere hhv. ja eller nej kontakten. Spørgsmålene læses højt af en quizmaster, og Arduinoopstillingen med tilhørende program holder så styr på, hvornår man svarer ja og nej. Det lykkedes ikke gruppen at få alle dele af prototypen til at virke. Der var bl.a. problemer med at få piberensermændene til at aktivere kontakterne. Selv om opstilling og program ikke fungerede helt efter hensigten, lykkedes gruppen stadig med at validere konceptet og vise ideens værd.

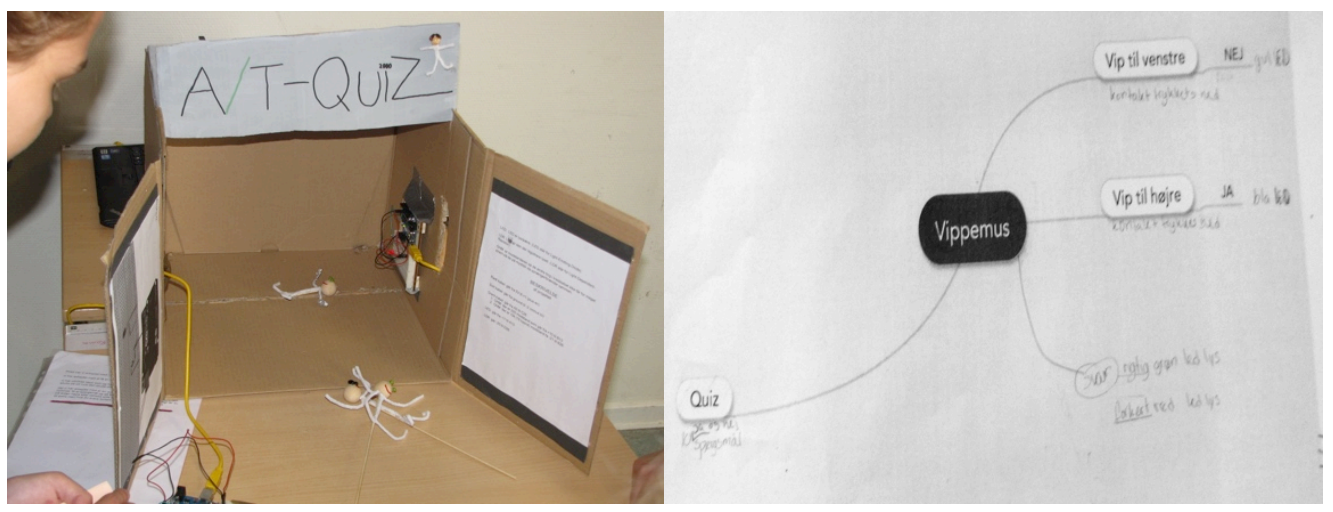

Figur 4. Vippe-musen

- Den glade skraldespand, var det af projekterne, hvor der var mest fokus på designet og ikke så meget på at få en prototype til at virke. Konceptuelt var projektet tænkt sådan, at man ved hjælp af en piezo-sensor monteret under bunden af spanden skulle detektere, når et stykke skrald rammer i spanden. Ligeledes skulle en bevægelsessensor checke om man ramte ved siden af. Display skulle benyttes til at vise grøn glad smiley eller rød sur smiley og lyd blev også diskuteret.

- Indeklimasystemet fik ændret titel til arbejdsklima. Det udviklede system byggede videre på projekt 03 - Love-o-meter i bogen, og havde til formål at måle henholdsvis temperatur og luftfugtighed $\mathrm{i}$ klasselokalet. Projektet implementerede på hardwaresiden en temperatursensor og fugtighedssensor, og mulighed for at udlæse værdier fra disse på 4 lysdioder. Derudover var der en knap til at skifte mellem, hvilken sensor der blev udlæst. Programmet udlæste både sensorværdierne på skærmen, og via forudbestemte intervaller på lysdioderne, således at den første lysdiode tænder, når temperaturen http://www.lom.dk 
f.eks. er mellem 15 og 20 grader, den næste mellem 20 og 25, o.s.v. Gruppen brugte meget tid på at forstå intervaller, og hvordan de kunne være inkluderende eller ekskluderende, og brugte også meget tid på at lave de rette inddelinger ift. både temperatur- og luftfugtighedssvingninger $\mathrm{i}$ omgivelserne.

\section{Elevernes spørgeskemaer}

Det elektroniske spørgeskema, blev bedt besvaret ugen efter naturvidenskabsfestivalen. Vi modtog i alt 19 besvarelser ud af 21 mulige. Langt de fleste stillede spørgsmål var kvalitative, men svarene kortfattede, derfor har vi fors $\varnothing$ gt at kategorisere indholdet for nogle af dem herunder, se tabellen.

Tabel 1. Oversigt over spørgsmål og svar

Hvordan har det været at lave projektet? Hvorfor?

- 15 svarede at det havde været sjovt,

- 6 svarede at det havde været spændende

- 5 svarede at det havde været svært/udfordrende

- 3 skriver noget med lære/lærerigt

"Hvilke ting har været lette?"

- 13 skriver at det har været let at samle / bygge ting ifm. Arduino

- 4 skriver det har været let at lave plancher / logoer /tegninger

- 1 skriver det har været let at lave "kodningen"

- 1 skriver der ikke har været noget, der var let.
"Hvilke ting har været svære?" blev følgende svar modtaget.

- 12 skriver at programmering / kodning har været svært

- 6 skriver noget med fejlfinding / rette / forkert

- 3 skriver at tegne / forstå diagrammer har været svært

- 2 skriver noget med at placere ledninger de rigtige steder

"Hvad synes du, du har lært af det projekt du har været med til at lave?"

- 9 skriver, at de er blevet bedre til at kode / programmere og finde fejl.

- 8 skriver at de har lært mere om komponenter og (robot)teknologi og hvordan man bygger.

- 1 skriver han/hun er blevet mere tålmodig ift. at finde fejl

- 1 skriver han/hun er blevet mere kreativ. 
De fleste elever syntes det var sjovt og spændende at deltage. I besvarelserne blev sjovt / spændende og svært / udfordrende ofte nævnes i sammenhæng. Samlet syntes de fleste af eleverne at det var nemmere at samle komponenterne end det var at programmere dem. De fleste af eleverne mener de er blevet bedre til at programmere, finde fejl og opbygning af kredsløb.

\section{Lærerens refleksioner}

Ved undervisningsforløbets afslutning bad vi underviseren reflektere skrifteligt over arbejdet med Arduino i klassen. Herunder summeres highlights fra besvarelsen.

Første highlight: Eksempler på hvordan eleverne lærte: De- og induktive aktiviteter og problemløsning igennem dialog.

Underviseren blev bedt om at beskrive hvad og hvordan eleverne lærte. Han lagde særlig vægt på at forløbet blev indledt med deduktive aktiviteter i form af opgaverne fra "Arduino Project Book". Det blev efterfulgt af mere induktive eksperimenter hvor børnene udviklede ideer og efterfølgende realiserede disse. Derudover fremhæver underviseren projektorientering, problemløsning og dialog som omdrejningspunkt for læreprocessen. Læreren udtrykker det således: ".. elevernes læring har baseret sig på en vekselvirkning mellem deduktive aktiviteter baseret på projekterne i "Arduino Projects Book" eller instruktioner fra en underviser og induktive aktiviteter, hvor arbejdsmetoden bedst kan beskrives som en vekselvirkning mellem at prøve sig frem og en mere systematisk eksperimentel metode. I alle sammenhænge har dialogen været omdrejningspunktet."

Problemløsning udgjorde en særlig udfordring i undervisningen og meget tid gik med at identificere tekniske problemer. Men dannede samtidig grobund for faglige og lærerige samtaler. Læreren udtrykker det således: "..en yderligere dimension der har styrket dialogens position i forløbet er, at mange af undervisningens aktiviteter $i$ sig selv har været et eksperiment. Hverken elever eller lærer har særligt ofte været i stand til hurtigt at konkretisere et givent problem. Det har ofte været $n \varnothing d v e n d i g t$ at tale sig ind til det centrale $i$ problemstillingen. I disse samtaler har der ofte været en høj grad af faglighed, idet hele opstillinger og programmer har været talt igennem for at identificere en fejl."

Underviseren sammenlignede også problemløsning i LEGO Mindstorm med Arduino: "Arduinoteknologien er vanskeligere tilgængelig end Lego Mindstorms. Dette fordrer et øget fokus på det teknologiske, når man arbejder med Arduino og følgeligt et større læringspotentiale. Kort sagt kan man sige, at man med Lego Mindstorms kan lære at løse problemstillinger og med Arduino kan lære hvordan man løser problemstillinger." 
Andet Highlight: Teknologi gør det abstrakte konkret "Hvad nu hvis vi...?"

Hvad kan teknologien i en undervisningssammenhæng, som en bog ikke kan? Underviseren beskrev det således: "Teknologien kan give konkrete eksempler på bogens teori. Teknologien er dynamisk og der kan relativt hurtigt følge op på undren: "Hvad nu hvis vi...?" Med teorien som eneste redskab er man overladt til at lave endnu en beregning eller diagramtegning, der ikke i sig selv appellerer til at tænke videre. Omvendt kommer man også på et tidspunkt til kort, hvis man satser på teknologien som eneste læringsmedium $i$ undervisningen. Spørgsmålet om teknologi vs. bog er således ikke et spørgsmål om enten eller. Med både bog og teknologi til rådighed i undervisningen får man lejlighed til at gøre den abstrakte og til tider virkelighedsfjerne teori mere konkret og vedkommende."

\section{Tredje hightlight: Fagligt lærte eleverne grundlæggende elektronik og programmering.}

Læreren blev bedt om at vurdere elevernes læring. Han beskrev det således: "Flertallet af elever er kommet godt i mål i forhold til de læringsmål, der var opstillet for projektet. Eleverne kendte ved forløbets slutning både navn og funktion på mange komponenter og sensorer, de ikke kendte før forløbet. Mange havde prøvet at omskrive større eller mindre dele af koden til deres projekt i overensstemmelse med deres projektbeskrivelse. Yderligere var det tydeligt, at mange kunne genkende de syntaktiske mønstre i det anvendte programmeringssprog.

Hvor eleverne ved projektets begyndelse naturligt nok var meget afhængige af at kunne følge deres grundbog og få hjælp fra lærerne oparbejdede de i løbet af projektet en vis fortrolighed med materialerne og en udstrakt selvstændighed i forhold til at løse de problemer der opstod.

Generelt oplevede jeg elevernes motivation og arbejdsindsats som værende høj i øbet af projektet."

Vedrørende dækning af fællesmålene udtrykte underviseren det således. "Fra fællesmålene var det særligt fagene fysik/kemi, matematik og engelsk, der blev bragt i spil. Målene for fysik/kemi og matematik knytter sig til arbejdet med teknologien og engelsk blev aktuelt, da stort set alle materialer var på engelsk. Konkret er eleverne blevet klogere på hvordan hard-og software er opbygget. De er også blevet klogere på, hvordan ny teknologi udvikles ved hjælp af hardware og software."

\section{Fjerde highlight: Lærerens anbefalinger}

I tabellen herunder beskrives lærerens anbefalinger til andre undervisere. 
Tabel 2. Lærerens anbefalinger til andre undervisere som skal anvende Arduino

- Afprøv først selv de deduktive aktiviteter fra "Arduino Project Book", der introducerer materialerne til læseren og sikrer progression og en gradvis udbygning i kendskabet til komponenter og kodefunktioner.

- Gennemfør aktiviterne fra "Arduino Project Book" med eleverne.

- Når den grundlæggende forståelse af teknologien er på plads kan der gives plads til mere legende og eksperimenterende aktiviteter, hvor eleverne selv udvikler projektideer med udvalgte sensorer.

- Problemløsning kommer til at fylde meget i forløbet. Man kan bevidst

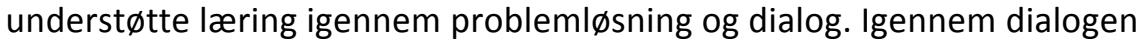
indkredses og artikuleres problemfeltet.

\section{Diskussion}

I det følgende har vi valgt at lave en tematiseret opsplitning af vores diskussion. Vi har valgt at lave denne, da disse temaer opstod under vores arbejde med resultaterne.

\section{Første tema. Værdien af de indledende opgaver.}

Det deduktive forløb i starten af projektet, hvor eleverne læste og fulgte opskrifterne i starter-kit projektbogen (Fitzgerald \& Hiloh 2012), har ud fra det vi så, været af stor betydning for deres efterfølgende mulighed for selv at opfinde, beskrive og udføre egne projekter. Det vil dog være forkert at kalde arbejdet med de indledende opgaver for udelukkende deduktivt, da der stadig var fejlfinding og eksperimentering involveret i dette. Vi så, hvordan eleverne gennem opgaverne først blev mere og mere fortrolige med at bygge opstillinger på breadboardet, fandt ud af at forbinde arduinoboardet til computeren og efterfølgende lave programmer, der kunne læse fra og skrive til opstillingerne på breadboardet. Der er ingen tvivl om, at det for mange af eleverne var svært og udfordrende at skulle arbejde med projektbogen, og at de på trods af bogens pædagogiske opbygning havde både forståelsesmæssige og sproglige problemer undervejs.

Dette arbejde gav alligevel eleverne et basalt indblik i elektroniske kredsl $\varnothing b$, sensorer og aktuatorer, programmering og fejlfinding, uden hvilken det ville være svært for dem at være kreative og innovative i det efterfølgende forløb. Man kan sige, at det indledende forløb var med til at st $\varnothing$ be de rette affordances omkring et ellers for eleverne ukendt område. 
Andet tema: Affordance og konstruktionistisk læring går hånd i hånd. Breadboardet. Affordance er den mulige interaktion mellem den lærende og artefaktet. Norman (1988) beskriver affordance som artefaktets invitation til brug, d.v.s. den interaktionsmulighed artefaktet tilbyder brugeren via bl.a. sit visuelle udtryk - udformning, placering, farve m.m. Hvis affordance er god, så er det oplagt for den lærende, hvad han skal gøre og hvordan artefaktet fungerer. God affordance i et køkken kan fx være, at håndtagene på lågerne giver en et fingerpeg om, hvordan låger skal åbnes. I projektet var det oplagt for eleverne at komponentbenene skulle stikkes ned i breadboardet dvs. god affordance, hvor hullerne i boardet signalerede at her kan der stikkes komponenter i. Med hensyn til netop breadboardet opstod imidlertid problemer i interaktionen, idet lednings-forbindelserne kun var beskrevet $\mathrm{i}$ bogen (s. 23), men der var ingen beskrivelse af disse forbindelser på oversiden af boardet, dette gjorde det un $\varnothing$ digt abstrakt for eleverne at gennemskue hvordan deres komponenter reelt blev forbundet. Eleverne gjorde derfor meget ud af at placere komponenter præcis som i opskriften i bogen, uden nødvendigvis at få en direkte forståelse det samlede kredsløb, dette var særligt tydelig i de første fors $\varnothing$ g. De kunne så i bogen nærstudere forskellen på serie og parallelforbindelse, og efterhånden udvikle en forståelse af breadboardets opbygning. Men breadboardet gjorde forståelsen af serie og parallelforbindelser unødigt kompliceret. Man kunne med en tusch oven på breadboardet tegne forbindelserne, dette ville forbedre den signallerede affordance og dermed forbedre børnenes læreproces. Man bør nok i undervisningen gøre noget ud af breadboardets virkemåde eller måske anvende alternative metoder som heller ikke kræver lodning, fx wire-wrapping (Wikipedia Wire Wrapping, 2015).

Elevernes design af nye affordances. Fra elevernes spørgeskemaer fremgår det, at mange har fundet det let at samle/bygge ting, mens mange mener at det svære har været at programmere systemet. Det går fint i hånd med den konstruktionistiske tankegang. Vi har lettere ved at forholde os til ting, der er håndgribelige og som er umiddelbart forståelige. Den proces, der er den fremherskende i byggeprocessen i elevernes projekter er netop at bruge kendte materialer som f.eks. piberensere, pap, papir og lim til at udforme projektopstillingerne. I "A/T Quizzen" benytter eleverne f.eks. også selv affordances ved at bygge/benytte en model af klasseværelset, således at en quizdeltager får en umiddelbar forståelse af det miljø han befinder sig i, og hvordan han deltager i quizzen, selv om det er i modelskala. Eller med "Motionsmotivatoren", hvor der blev lavet en papirmodel af et fyldt popcornbæger for at illustrere scenariet og objektiverne med projektet bedre.

Fysisk og virtuel konstruktion. Hvis man fors øger at sammenligne processen omkring det at bygge henholdsvis hardware og software i projektet, er det umiddelbart let at uddrage at hardwareopbygningen er en mere konkret, fysisk http://www.lom.dk 
og taktil oplevelse for eleverne, hvorimod softwareopbygningen er mere abstrakt og virtuel oplevelse, hvor man med tekst skal skrive kommandoer, der får teknologien til at opføre sig, som man gerne vil have den til. Det foregår sågar i et miljø, hvor der ikke er nogen umiddelbar sammenhæng med den fysiske verden, før man endelig kan uploade det kompilerede program til Arduinoboardet. Der er flere mentale koblinger, der skal på plads her, og en klar mangel på affordances ift. at give eleverne en umiddelbar forståelse for, hvad de skal gøre. Norman (1999) skelner således også mellem opfattede og virkelige affordances, hvor fysiske objekter har virkelige affordances, mens virtuelle objekter, som f.eks. knapper og slidere i en grafisk brugerflade har opfattede affordances. Tekstbaseret programmering kræver, ud over en forståelse af begreber som variable, funktioner, kontrolstrukturer og løkker, også, at man er god til at huske det specifikke navn, den specifikke skrivemåde og struktur på de komponenter, man gerne vil benytte i sit program. Det er på sin vis lige så svært som at lære at skrive på dansk, tysk eller engelsk, og kræver at stavning, grammatik og tegnsætning i $\varnothing$ vrigt er $100 \%$ korrekt, for ellers vil programmet ikke kompilere eller ikke blive udført korrekt. Det ville svare til at man iht. ovenstående eksempel med affordance og køkkenlågerne skulle slå op i en manual de første mange gange, man skulle åbne en låge, for at kunne huske proceduren. For at arbejde på en mere konstruktionistisk måde med programmering fors $\varnothing$ gte vi os i starten af projektet med at bruge forskellige visuelle programmeringsværktøjer, der netop bruger designprincippet genkendelse fremfor genkaldelse, hvor man bruger visuelle komponenter til at opbygge sit program med. Dette lykkedes dog ikke pga. disse programmers krav til bl.a. de computere de skulle køre på, internetforbindelse m.m. Derfor har vi besluttet at afprøve disse værktøjer i et kommende projekt.

Hvis konstruktionistisk læring (og dermed eksperimenterende læring) skal være virkningsfuld, er det vigtigt, at affordance i læremidlerne er intuitiv forståelig og definerer mulige handlemuligheder. På den måde vil en god affordance kunne forbedre læreprocessen.

Tredje tema: Eleverne som kreative producenter. Ideudvikling, design og prototyper.

Eleverne fik i det samlede forløb praktisk erfaring med udvikling af interaktive prototyper. Fra de indledende opgaver, hvor eleverne lærte teknogien at kende ved at gennemføre grundlæggende $\varnothing$ velser $\mathrm{fx}$ opbygning af et simpelt elektrisk kredsløb med modstand, kontakter og lysdiode efterfulgt af mere komplekse opgaver med temperatur-måler, som skulle få forskellige lysdioder til at lyse afhængig af temperatur. Det var nødvendigt at have en basal viden og erfaring for siden at kunne realisere egne ideer. De indledende opgaver sikrede en tættere kobling mellem ide og muligheder med den udvalgte teknologi. Ideerne blev formuleret i velfærdsteknologidomænet, og det var 
altså ideer som underst $\varnothing$ ttede sundhed og læring fx, den glade skraldespand, pulsindikatoren eller motionsmotivatoren.

Udviklingsfaserne var således, forundersøgelse (de indledende opgaver), ideudvikling, præsentation af ideer, prototypeudvikling, præsentation af prototyper og evaluering af forløbet. Prototypeudviklingen forløb som en proces, hvor eleverne gradvist forfinede deres designs. I denne proces forekom praktisk problemløsning med elektronik, komponenter og programmering.

Det samlede udviklingsforløb kan beskrives som et eksemplarisk for designdelen af valgfaget Håndværk og design, som det står beskrevet i de nye forenklede fællesmål som træder i kraft i skoleåret 2015/2016 (Retsinformation Fællesmål, 2014). I de nye fællesmål fremhæves bl.a. at eleven kan udvikle og realisere ideer med inspiration fra hverdagsliv med digitale værktøjer. Eleverne anvendte desuden innovative og entreprenante udviklingsmetoder. Udviklingsfaserne i det beskrevne projekt er netop dem man anvender i innovativ designmetodik (Majgaard, 2011). For at fremme det innovative element udviklede eleverne Mindmaps, som de præsenterede i flere varianter undervejs i forløbet. Derudover blev der på baggrund af elevernes ideer bestilt sensorer hjem, som ikke indgik i den oprindelige værktøjskasse f.eks. pulssensor til pulsmåling og sonarsensor til hastighedsmåling. I de nye fællesmål under IT og medier, fremhæves eleven som målrettet og kreativ producent de ny fællesmål (Retsinformation Fællesmål, 2014; EMU Danmarks læringsportal, IT og Medier). Hvilket stemmer meget fint overens med de kreative protototyper eleverne i 8. c udarbejdede og den rolle som kreative producenter som eleverne indtog.

Fjerde tema: Debugging og læring.

En af de ting vi bed mærke i under projektforløbene, og som også delvist kommer til udtryk gennem elevernes spørgeskema, er den sandkasse man arbejder i, når man arbejder med Arduino. Sandet er mere finkornet end f.eks. Lego Mindstorms, hvilket giver en masse muligheder, men også potentielle faldgruber. At bygge noget som skulle virke, men som alligevel ikke gør det, kan måske umiddelbart fremkalde skuffelse eller ligefrem irritation eller vrede hos den der har bygget. Vi så det ofte under arbejdet med de første indledende opgaver i bogen, hvor man fra bogen kunne se hvordan den endelige opstilling skulle virke. Løsningen for langt de fleste var at nærlæse instruktionerne igen og minutiøst gennemgå både tekst, kredsløb og kode for at finde ud af, hvad de havde misset. Nogle elever gav lettere op end andre og som undervisere/vejledere måtte vi træde til og hjælpe med at forklare emner, gennemgå opstilling, software m.m. Senere i processen, hvor eleverne arbejdede med deres egne projekter havde de ikke bogen som livline til at debugge og fejlsøge deres produkt, når det ikke virkede, og derfor blev det sværere for dem at skyde sig ind på fejlkilder. Det største spørgsmål var ofte, 
om det var software eller hardware der fejlede. Igen måtte underviser/vejleder ofte træde til og sammen med eleverne gennemgå deres konstruktion fra ende til anden.

Vi er efter projektforløbet overbeviste om, at når vi arbejder med læring på den konstruktionistiske måde som vi har gjort her, er det af afgørende betydning at fejlsøgning også er en del af læringsprocessen. Dels lærer eleverne at arbejde mere systematisk med fejlfinding. Dels er det netop her eleverne bruger vores vejledning og kompetencer til selv at opnå en bedre forståelse af det, de har bygget. Hvis man som lærer kan leve med at være mere vejleder end underviser, er muligheden for at arbejde projektorienteret $\mathrm{i}$ et miljø, hvor der er råd og tid til at lave fejl, af stor betydning for de erfaringer og den lærdom eleverne tilegner sig. Vores spørgeskemaunders $\varnothing$ gelse viste at eleverne ofte nævnte "svært" og "udfordrende" sammen med "sjovt" og "spændende", hvilket kunne indikere, at de rent faktisk har nydt at arbejde i et miljø, hvor mange ting kunne gå og gik galt, men at de samtidig oplevede at få Iøst problemerne og alligevel få mange ting til at virke.

Læringen der foregik baserede sig i høj grad på "Trial and error learning", som kan oversættes med læring igennem fors $\emptyset \mathrm{g}$ og fejl, hvilket Bateson (2005) beskriver som en grundlæggende måde at lære på. Jo mindre eleverne ved om et område, jo mere tilfældige kan deres fors $\varnothing \mathrm{g}$ på at løse problemerne virke. Men efterhånden som de lærer de forskellige komponenter og systemniveauer at kende, får de nemmere ved at pejle sig ind på, hvordan de kan optimere systemets virkemåde. Papert (1993) fremhæver læring igennem debugging, som et særkende ved konstruktionistisk læring. Læreren i klassen anvender sætningen "hvad nu hvis...", som en af de særlige kendetegn ved læreprocessen, og det var både ham selv og eleverne, der anvendte denne sætning, når de optimerede Arduino-projekterne. "Hvad nu hvis..." blev både anvendt i forbindelse med problemløsning, men også når de ville fors $\varnothing$ ge at videreudvikle den digitale adfærd.

Femte tema: Fysik/kemi - Elektronisk og digital styring. Inden for produktion og teknologi i kompetencemål og færdigheds- og vidensmål for faget fysik/kemi efter 9. klassetrin, beskrives det at, "Eleven kan designe og gennemføre undersøgelser vedrørende elektronisk og digital styring. Eleven har viden om elektroniske kredsløb, simpel programmering og transmission af data." (Retsinformation Fællesmål, 2014).

Det beskrevne projekt fokuserer netop på koblingen mellem analog og digital elektronik. Sensorerne samler analoge data op i omverdenen $\mathrm{fx}$ temperatur eller puls, som omdannes til digitale data, der behandles i et program. Resultatet kan fx være, at tal skrives ud på skærmen, et køretøj sætter i bevægelse eller en diode begynder at lyse. 
Derudover fik eleverne en grundlæggende viden og praktisk erfaring med komponenter og grundlæggende kredsløbsteknik, herunder viden om serie- og parallelforbindelser.

\section{Konklusion}

Hvordan kan Arduino og konstruktionistisk læring berige undervisningen i 8. c?

- herunder styrker og faldgrupper ved teknologi og konstruktionistisk undervisning.

Arduino og starterkit'et kunne i høj grad berige undervisning i 8.c. Eleverne oplevede, hvordan de kunne forme det 21.århundredes teknologi efter deres egne ideer.

Fagligt fik de en dybere forståelse for programmering og robotteknologi, og herigennem også kontakt med fagområder indenfor matematik, fysik og engelsk. Forløbet var opdelt i indledende opgaver og projektfaserne.

Igennem de indledende opgaver fik de en grundlæggende forståelse for kredsløbsteknik, virkemåde og samspillet mellem sensorer, aktuatorer og programmering af Arduino-kontrolleren. Projektfaserne var et mere kreativt forl $\varnothing b$, hvor eleverne selv fandt på og udviklede protototyper.

Problemløsning og dialog var kernen i læreprocessen. Der opstår en række uundgåelige begynderfejl, når man begynder at bygge og programmere elektronik, f.eks. fejl i programkoden, fejl i valg af komponenter eller fejl i, hvordan de var forbundet. Man måtte derfor med dialog gennemgå hele opstillingen, for at indkredse problemet. Dette er tidskrævende, lærerigt og udfordrende for både lærer og elever. Eleverne mente særligt at kodningen drillede.

Arduino gjorde den abstrakte viden om kredsløbsteknik og robotteknologi konkret. Det åbnede op for kreativt at udforske og eksperimentere med teknologiens muligheder og potentialer. Det blev særligt synligt i projektfaserne, hvor der bl.a. blev udviklet et løbende vækkeur, hurtig-boldmåleren samt motions-motivatoren.

Affordance og konstruktionistisk læring skal gå hånd $\mathrm{i}$ hånd, hvis eleverne skal kunne eksperimentere frit. Det er vigtigt, at læremidlerne er intuitivt forståelige og definerer mulige handlemuligheder. På den måde vil en bedre affordance i tool-kittet kunne forbedre læreprocessen. Dette er en udfordring med Arduino, der kan afhjælpes ved at gennemføre indledende bundne opgaver, hvor eleverne kommer i fysisk eller visuel kontakt med de tekniske komponenter, og får en introduktion til deres virkemåde. The Arduino Project Book yder god støtte i den proces. 
Der er mange udfordringer $i$ at anvende Arduino, og der er ingen tvivl om, at det kræver en særlig indsats af underviseren. Vi mener dog, at denne indsats retfærdiggøres, når man ser hvordan den teknologiske innovation i projekterne motiverer eleverne til at arbejde med mange forskellige fagområder, mens de Iøser et konkret samfundsmæssigt problem.

\section{Referencer}

Bateson, G. (2005). Mentale systemers økologi. København: Akademisk forlag.

Binau, C. F. \& Mortensen, K. (2015). ISI-metoden. Lærervejledning. Danish Science Factory. Hentet fra http://isi2015.danishsciencefactory.dk/sites/default/files/files/laererv ejledning_a4_isi_endelig_0.pdf

Darsø, L. (2012). Innovationspædagogik. Kunsten at fremelske innovationskompetence, Samfundslitteratur.

Fitzgerald, S., \& Hiloh, M. (2012). The Arduino Projects Book: Arduino LLC.

Johnson, L., Adams Becker, S., \& Hall, C. (2015). 2015 NMC Technology Outlook for Scandinavian Schools: A Horizon Project Regional Report. Austin, Texas: The New Media Consortium. http://cdn.nmc.org/media/2015-technology-outlook-scandinavianschools-EN.pdf

Larman, C., \& Basili, V. R. (2003). Iterative and incremental development: A brief history. Computer, 36(6), 47-56.

Majgaard, G. (2014). Teaching Design of Emerging Embodied Technologies. I P. Isaias, \& K. Blashki (red.), Human-Computer Interfaces and Interactivity: Emergent Research and Applications (s. 188-206). IGI global.

Majgaard, G., Hansen, J. J., Bertel, L. B., \& Pagh, A. (2014). Fra digitalt design til fysisk udtryk - anvendelse at 3-d-printere og NAO-robotter i folkeskolen. Mona, 2014(4), 7-26.

Majgaard, G., Misfeldt, M. \& Nielsen, J. (2011). How Design-Based Research, Action Research and Interaction Design Contributes to the Development of Designs for Learning. Designs for Learning, 4(2), 8-21.

Nielsen, J., \& Majgaard, G. (2014). Constructionist Prototype Programming in a First Semester HCI Course for Engineering Students. I P. Isaias, \& K. Blashki (red.), Human-Computer Interfaces and Interactivity: Emergent Research and Applications. (s. 50-71). IGI global.

Nielsen, J. (1993). Iterative User-Interface Design. Computer, 26(11), 32-41. doi: $10.1109 / 2.241424$

Norman, D. A. (1988). The Design of Everyday Things. New York, NY: Basic Books 
Norman, D. A. (1999). Affordance, conventions, and design. interactions, 6(3), 38-43. doi:10.1145/301153.301168

Papert, Seymour, (1993). Mindstorms Children, Computers, and Powerful Ideas, New York, NY: Basic Books.

Rusk, N., Resnick, M., Berg, R., \& Pezalla-Granlund, M. (2008). New Pathways into Robotics: Strategies for Broadening Participation. Journal of Science Education and Technology, 17(1), 59-69. doi: $10.1007 / \mathrm{s} 10956-007-9082-2$

Rogers, Y., Sharp, H., \& Preece, J. (2011). Interaction Design: Beyond Human-Computer Interaction (3rd ed.): John Wiley and Sons, Ltd.

Rohrbach, B. (1969). Kreativ nach Regeln - Methode 635, eine neue Technik zum Lösen von Problemen, Absatzwirtschaft, 12(19), 73-75.

Schön, A. D. (2001). Den reflekterende praktiker - Hvordan professionelle tænker, når de arbejder. Klim.

Sølberg, J. (2015). Innovation, Science og Inklusion 2015. Slutrapport af ISI 2015. Københavns Universitet. Hentet fra http://isi2015.danishsciencefactory.dk/sites/default/files/files/slutrap port_isi_2015_0.pdf

Akker, J. V. d., Gravemeijer, K., McKenney, S., \& Nieveen, N. (2006).

Educational Design Research: Routledge.

\section{Links}

Arduino 2015 http://www.arduino.cc/ senest downloadet 20-01-2015

Fælles Mål 2009 - Fysik/kemi. Faghæfte 16. http://www.uvm.dk/Service/Publikationer/Publikationer/Folkeskolen /2009/Faelles-Maal-2009-Fysik-Kemi/Formaal-for-faget-fysik-kemi senest downloadet 20-01-2015

Wiki wire wrapping, 2015. https://en.wikipedia.org/wiki/Wire_wrap downloadet 20-01-2015

Retsinformation Fællesmål, 2014. Bekendtgørelse om formål, kompetencemål og færdigheds- og vidensmål for folkeskolens fag og emner (Fælles Mål), https://www.retsinformation.dk/Forms/R0710.aspx?id=164145, senest downloadet 20-01-2015

EMU Danmarks læringsportal, IT og Medier. http://www.emu.dk/modul/it-og-medier-0, senest downloadet 20-012015 